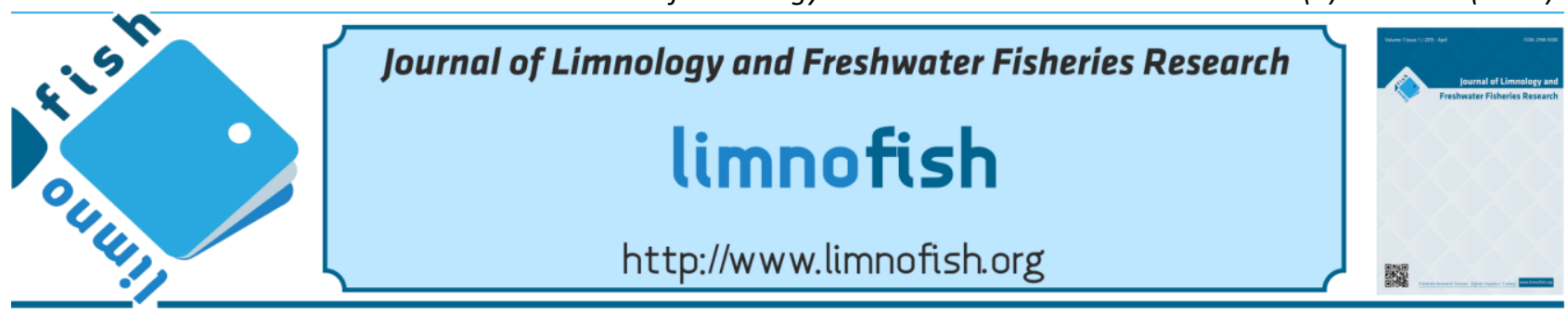

\title{
A Study on Zooplankton Fauna and Some Water Quality Parameters of Kozan Dam Lake (Adana, Turkey)
}

\author{
Cem TUGYAN (D), Ahmet BOZKURT* (D) \\ Faculty of Marine Sciences and Technology, İskenderun Technical University, İskenderun, Hatay, Turkey
}

\section{A B STR ACT}

Some water quality parameters (Secchi disk depth, water temperature, dissolved oxygen, $\mathrm{pH}$, conductivity, chlorophyll a, $\mathrm{NO}_{2}-\mathrm{N}, \mathrm{NO}_{3}-\mathrm{N}, \mathrm{NH}_{4}-\mathrm{N}, \mathrm{PO}_{4}-\mathrm{P}$ ) and zooplankton fauna were determined in the Kozan Dam Lake. While the quality of the reservoir water was first class water in terms of temperature, dissolved oxygen, $\mathrm{NH}_{4}-\mathrm{N}, \mathrm{PO}_{4}-\mathrm{P}$, it was second-class water in terms of conductivity, $\mathrm{pH}$, $\mathrm{NO}_{3}-\mathrm{N}$. In total, 50 zooplankton species belonging to 26 families were determined (29 species belonging to 17 families from Rotifera, 15 species belonging to 7 families from Cladocera and 6 species belonging to 2 families from Copepoda). Brachionidae (Rotifera) was the most species rich family with 7 species, followed by Chydoridae (Cladocera) and Cyclopidae (Copepoda) with 6 and 5 species respectively. The most dominant species were Synchaeta pectinata $(38.33 \%)$ from Rotifera, Bosmina longirostris (5.71\%) from Cladocera and Cyclops vicinus $(0.67 \%)$ from Copepoda. At the same time, the species found in every month were Asplanchna priodonta, Polyarthra dolichoptera, Bosmina longirostris, Ceriodaphnia pulchella, Cyclops vicinus and Diacyclops bicuspidatus. In the study, Rotifera was the most abundant group with $67 \%$, followed by Cladocera with $29 \%$ and Copepoda with $4 \%$. On the other hand, total Rotifera was found mostly in December (10099 individual/ $\left.\mathrm{m}^{3}\right)$, Cladocera in January (4928 ind. $/ \mathrm{m}^{3}$ ) and Copepoda in September (1091 ind. $/ \mathrm{m}^{3}$ ).

Keywords: Rotifera, Cladocera, Copepoda, Kozan Dam Lake

\section{ARTICLE INFO}

RESEARCH ARTICLE

$\begin{array}{lll}\text { Received } & : 11.03 .2019 \\ \text { Revised } & : 27.05 .2019 \\ \text { Accepted } & : 28.05 .2019 \\ \text { Published } & : 25.12 .2019\end{array}$

DOI:10.17216/LimnoFish.538344

* CORRESPONDING AUTHOR

ahmet.bozkurt@iste.edu.tr Phone : +903266141693(3405)

\section{Kozan Baraj Gölü (Adana, Türkiye) Zooplankton Faunası ve Bazı Su Kalite Parametreleri Üzerine Bir Çalışma}

Öz: Kozan Baraj Gölü'nde bazı su kalitesi parametreleri (Secchi derinliği, su sıcaklığı, çözünmüş oksijen, pH, iletkenlik, klorofil $a$, $\mathrm{NO}_{2}-\mathrm{N}, \mathrm{NO}_{3}-\mathrm{N}, \mathrm{NH}_{4}-\mathrm{N}, \mathrm{PO}_{4}-\mathrm{P}$ ) ve zooplankton faunası belirlenmiştir. Baraj gölü suyu sıcaklık, çözünmüş oksijen, $\mathrm{NH}_{4}-\mathrm{N}, \mathrm{PO}_{4}-\mathrm{P}$ açısından birinci sınıf su iken, iletkenlik, $\mathrm{pH}, \mathrm{NO}_{3}-\mathrm{N}$ açısından ikinci sınıf sudur. Rotifera'dan 17 familyaya ait 29 tür, Kladosera'dan 7 familyaya ait 15 tür ve Kopepoda'dan 2 familyaya ait 6 tür olmak üzere toplam 50 tür tespit edilmiştir. Brachionidae (Rotifera) 7 türle en zengin familya olup, bunu 6 ve 5 tür ile Chydoridae (Cladocera) ve Cyclopidae (Copepoda) familyalarının takip ettikleri belirlenmiştir. En baskın türün Rotifera'dan Synchaeta pectinata (\%38,33), Kladosera'dan Bosmina longirostris (\%5.71) ve Kopepoda'dan Cyclops vicinus (\%0.67) olduğu belirlenmiştir. Araştırmada her ay bulunan türler rotiferlerden Asplanchna priodonta, Polyarthra dolichoptera, kladoserlerden Bosmina longirostris, Ceriodaphnia pulchella, kopepodlardan Cyclops vicinus ve Diacyclops bicuspidatus'tur. Çalışmada Rotifera'nın \%67 ile en çok bulunan grubu oluşturduğu, bunu \%29 ile Kladosera'nın ve \%4 ile Kopepoda'nın takip ettiği bulunmuştur. Öte yandan toplam Rotifera'nın en çok Aralık'ta (10.099 birey/m³), Kladosera'nın Ocak'ta (4.928 birey/m³ $)$ ve Kopepoda'nın Eylül'de $\left(1.091\right.$ birey $\left./ \mathrm{m}^{3}\right)$ bulundukları belirlenmiştir.

Anahtar kelimeler: Rotifera, Kladosera, Kopepoda, Kozan Baraj Gölü

How to Cite

Tugyan C, Bozkurt A, 2019. A Study on Zooplankton Fauna and Some Water Quality Parameters of Kozan Dam Lake (Adana, Turkey). LimnoFish. 5(3): 147-158. doi: 10.17216/LimnoFish.538344

\section{Introduction}

Turkey has very rich potential in terms of lakes and dam lakes. The dams have been built in order to control the regime of the rivers and meet the various needs (eg. drinking water supply, irrigation, flood control, and energy generation) of the people have increased this potential in recent years.

The zooplankton have long been recognized as a secondary producer by occupying almost middle positions of the food chain and indicate environmental status in a given time (Khan 2003). 
They have been known as an important energy resource for small sized fish that, in turn, provide energy to piscivorous fish consumers higher up in the food web in fresh water. Zooplankton is known to respond quickly to environmental conditions, and only a few attempts have been made to use the zooplankton community to evaluate the quality of aquatic ecosystems (Lougheed and Chow-Fraser 2002).

Crustacean plankton has been described as preferred fish food items by several authors (Zaret 1972; Dodson 1974; Ayodele and Adeniyi 2006). They are preferred by fishes to their Rotifera counterparts for several reasons. First, they are relatively bigger, and planktivorous fishes which practice size selective predation often prefer them to the rotifers (Ayodele and Adeniyi 2006; Brandl 2002). Crustaceans are more important than rotifers in the transfer of energy from autotrophic phytoplankton to fishes based on their ecological niche in freshwater systems (Williamson 1983). Cyclopoid copepods have been described as effective predators of rotifers, and so are some calanoid species which may include rotifers in their diets too (Williamson and Butler 1986; Schulze and Folt 1990). Aside their importance in fisheries, crustacean plankton (some cyclopoids) are also ecologically important by suppressing mosquito larvae (Alekseev 2002). That's why, studies on zooplanktonic organisms are important for the freshwater ecosystem.

Zooplankton are known to respond quickly to environmental conditions, and only a few attempts have been made to use the zooplankton community to evaluate the quality of aquatic ecosystems (Lougheed and Chow-Fraser 2002). Some zooplankton species are used in various studies as indicators of water quality, pollution and eutrophication status due to their sensitivity to environmental changes (Ruttner-Kolisko 1974; Sharma 1983; Saksena 1987).

A detailed study on the zooplankton fauna in Kozan Dam Lake had not been done before. This study was done to obtain insight into the composition of the zooplankton fauna of the dam lake and to contribute to the knowledge of the biological diversity of inland waters in Turkey.

\section{Materials and Methods}

The study was carried out between January 2011 and December 2011 on Kozan Dam Lake, which has $6 \mathrm{~km}^{2}$ lake area, in the Adana province Kozan district
(Figure 1). Zooplankton samples were taken from 4 stations with horizontal and vertical hauls by using $60 \mu \mathrm{m}$ mesh size plankton nets on a monthly basis for systematic analyses. On the other hand, zooplankton abundance was determined from the samples taken from first two stations (station 1 and station 2). Considered to be enough for analysis, two liters of water samples were collected from every water layer (surface, middle and deep) of first and second stations using Nansen Bottles. Water quality parameters and chlorophyll $a$ were analysed from water samples.

One lt and $0.5 \mathrm{lt}$ of the water collected with water sampler was used for chlorophyll $a$ analysis and chemical analysis respectively. The remaining part (4.5 lt) was filtered from a collector having a mesh size of $60 \mu \mathrm{m}$ and zooplankton was fixed in $100 \mathrm{cc}$ glass jars. Dissolved oxygen, water temperature, $\mathrm{pH}$ and conductivity were measured directly in the field by means of digital instruments (oxygen and temperature: YSI model 52 oxygen meter; $\mathrm{pH}$ : YSI $600 \mathrm{pH}$ meter; conductivity: YSI model 30 salinometer). Merck spectroquant Nova 60 spectrophotometer and its procedure were used to determine $\mathrm{NO}_{2}-\mathrm{N}, \quad \mathrm{NO}_{3}-\mathrm{N}, \mathrm{NH}_{4}-\mathrm{N}, \quad \mathrm{PO}_{4}-\mathrm{P}$; the method in APHA 1995 was used to determine chlorophyll $a$ spectrophotometrically. Secchi depth was measured using a Secchi disk with a diameter of $20 \mathrm{~cm}$.

At the stations, the lowest depth was $31 \mathrm{~m}$ (1. station), $26 \mathrm{~m}$ (2. station), $12 \mathrm{~m}$ (3. station) and $10 \mathrm{~m}$ (4. Station) in October and the highest depth was $47,44,31$ and $26 \mathrm{~m}$ in May, respectively. Therefore, the depth was approximately $18 \mathrm{~m}$ in the year, while the mean depths were 45, 39, 20 and $18 \mathrm{~m}$.

All zooplankton samples were fixed in $4 \%$ formaldehyde. Species identifications were made using a binocular microscope according to the works of Edmondson (1959), Scourfield and Harding (1966), Dussart (1967), Kiefer and Fryer (1978), Koste (1978), Negrea (1983), Segers (1995), De Smet (1996, 1997), Nogrady and Segers (2002), Hołynska et al. (2003) and Benzie (2005).

Zooplankton count was performed using an inverted microscope in a petri dish with $2 \mathrm{~mm}$ lines at the bottom. The sample cup was made homogenized by shaking and 2 cc sub-sample was taken from the cup and it was placed in a petri dish and the individuals of each species were separately counted. This process has been repeated 4-5 times. 


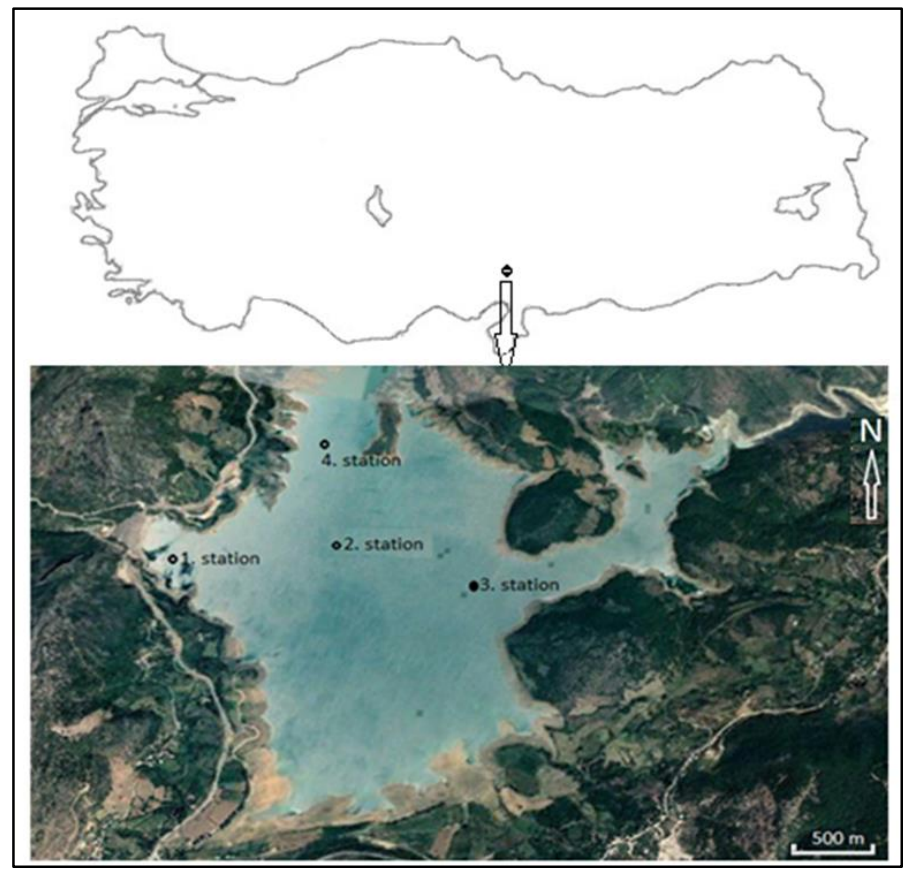

Figure 1. Kozan Dam Lake and Sampling Stations

CTM tolerance of the species (SPSS 20.1). Duncan's multiple range test (DMRT) was carried out for post hoc mean comparisons. Regression analysis was also carried out to evaluate the relationship between acclimation temperature and CTMin and CTMax (p $\leq 0.05)$.

\section{Results}

Maximum, minimum and average values of some water quality criteria were given in Table 1 .

Table 1. Maximum, minimum and average values of some water quality parameters.

\begin{tabular}{|c|c|c|c|}
\hline Parameter & Min. & Max. & $\operatorname{Mean} \pm$ stdev. \\
\hline Secchi depth (m) & 1.40 & 4.50 & $2.75 \pm 0.91$ \\
\hline W. Temp $\left({ }^{\circ} \mathrm{C}\right)$ & 7.97 & 24.57 & $16.51 \pm 5.32$ \\
\hline Chl. a $\left(\mathbf{m g} / \mathrm{m}^{3}\right)$ & 1.71 & 7.39 & $2.96 \pm 1.44$ \\
\hline Cond. $(\mu \mathrm{S} / \mathrm{cm})$ & 372.00 & 436.00 & $406.08 \pm 17.04$ \\
\hline DO (mg/l) & 5.40 & 11.53 & $7.92 \pm 1.85$ \\
\hline pH & 6.75 & 9.42 & $8.22 \pm 0.51$ \\
\hline $\mathrm{NO}_{2}-\mathrm{N}$ (mg/l) & 0.002 & 0.11 & $0.024 \pm 0.03$ \\
\hline $\mathrm{NO}_{3}-\mathrm{N}(\mathrm{mg} / \mathrm{l}$ & 4.31 & 9.25 & $6.36 \pm 1.54$ \\
\hline $\mathrm{NH}_{4}-\mathrm{N}(\mathrm{mg} / \mathrm{l}$ & 0.056 & 0.188 & $0.123 \pm 0.04$ \\
\hline $\mathrm{PO}_{4}-\mathrm{P}(\mathrm{mg} / \mathrm{l})$ & 0.010 & 0.053 & $0.03 \pm 0.012$ \\
\hline
\end{tabular}

At the stations, the lowest water depth was $31 \mathrm{~m}$ (1. st), $26 \mathrm{~m}$ (2. st), $12 \mathrm{~m}$ (3. st) and $10 \mathrm{~m}$ (4. st) in October and the highest water depth was $47,44,31$ and $26 \mathrm{~m}$ in May, respectively. Therefore, the annual water depth change was approximately $18 \mathrm{~m}$, while the mean depths were $45,39,20$ and $18 \mathrm{~m}$ respectively.

Secchi disk depth reached the maximum depth of $4.50 \mathrm{~m}$ in April (station 2) and the minimum depth of
$1.4 \mathrm{~m}$ on December (station 2), with a mean value of $2.75 \pm 0.91 \mathrm{~m}$ (Figure 2A). Water temperature varied from $7.97^{\circ} \mathrm{C}$ (December at second station) to $24.57^{\circ} \mathrm{C}$ (June at second station) with a mean value of $16.51 \pm 5.32^{\circ} \mathrm{C}$ (Figure $2 \mathrm{~B}$ ). Mean chlorophyll $a$ concentration was $2.96 \pm 1.44 \mathrm{mg} / \mathrm{m}^{3}$ with a range from $1.71 \mathrm{mg} / \mathrm{m}^{3}$ (at first station) in May to $7.39 \mathrm{mg} / \mathrm{m}^{3}$ in March (Figure 2C). The conductivity value varied from $372 \mu \mathrm{S} / \mathrm{cm}$ (September at first station) to $436 \mu \mathrm{S} / \mathrm{cm}$ (May at second station) with a mean value of $406.08 \pm 17.04$ $\mu \mathrm{S} / \mathrm{cm}$ (Figure 2D). Dissolved oxygen varied from $5.4 \mathrm{mg} / \mathrm{l}$ (at first station) in July to a peak of $11.53 \mathrm{mg} / \mathrm{l}$ (second station) in January with a mean value of $7.92 \pm 1.85 \mathrm{mg} / 1$ (Figure $2 \mathrm{E}$ ). $\mathrm{pH}$ value did not vary much between the stations. The minimum, maximum and mean $\mathrm{pH}$ values were 6.75 (July at first station), 9.42 (March at first station) and $8.22 \pm 0.51$ respectively (Figure $2 \mathrm{~F}$ ). Nitrite nitrogen reached the maximum concentration of $0.11 \mathrm{mg} / \mathrm{l}$ (February at first station) and minimum concentration of $0.002 \mathrm{mg} / \mathrm{l}$ (October at second station), with a mean value of $0.024 \pm 0.03$ $\mathrm{mg} / \mathrm{l}$ (Figure 2G). Nitrate nitrogen (annual average $6.36 \pm 1.54 \mathrm{mg} / \mathrm{l}$ ) varied from $4.31 \mathrm{mg} / \mathrm{l}$ (October at second station) to $9.25 \mathrm{mg} / \mathrm{l}$ (May at second station) (Figure 2H), and ammonium nitrogen (annual average $0.123 \quad \pm 0.04 \quad \mathrm{mg} / \mathrm{l}$ ) varied from $0.056 \mathrm{mg} / \mathrm{l}$ (February at first station) to $0.188 \mathrm{mg} / \mathrm{l}$ (October at second station) (Figure 2I). The maximum, minimum, and mean phosphate values were $0.053 \mathrm{mg} / \mathrm{l}$ (November at first station), $0.010 \mathrm{mg} / \mathrm{l}$ (January at second station), and $0.03 \pm 0.012 \mathrm{mg} / \mathrm{l}$, respectively (Figure $2 \mathrm{~J}$ ). 


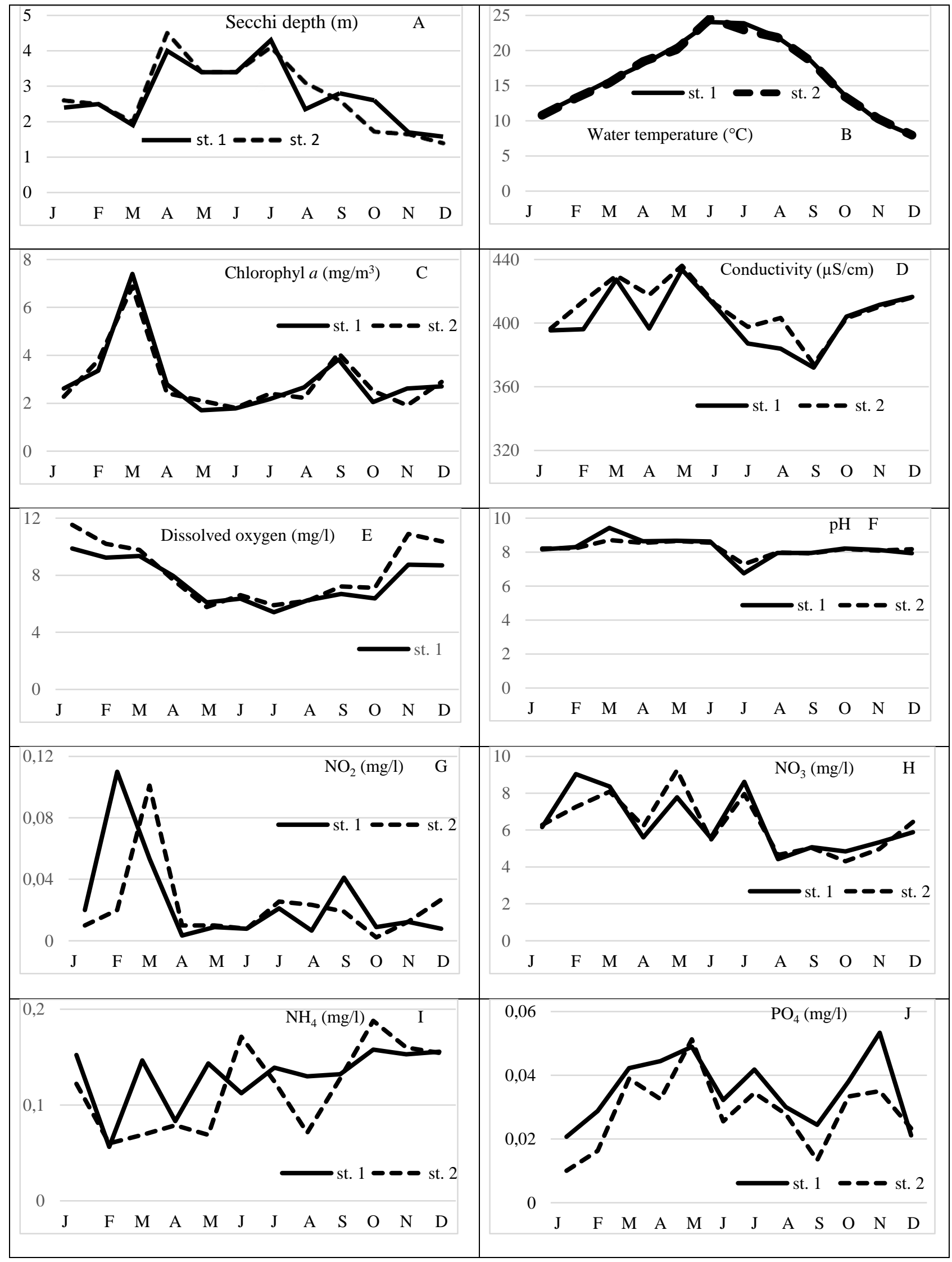

Figure 2. Some water quality parameters in the study 
In the study, a total of 50 zooplankton species were identified, including 29 from rotifers, 15 from cladocerans and 6 from copepods.

Seventeen families were identified from Rotifera and Brachionidae was the most species rich family with 7 species, followed by Collothecidae, Hexarthridae, Lecanidae, Lepadellidae, Synchaetidae and Trichocercidae with 2 species each one. The remaining families from Rotifera were found to contain only one species in each one (Table 2). Seven families found from Cladocera, Chydoridae was the most species rich family with 6 species, followed by Daphniidae with 4 species and other families were represented only one species each one (Table 2). Two families were detected from Copepoda, Cyclopidae was the richest family with 5 species, but Ameiridae (Harpacticoida) was represented by only one species.

Table 2. Zooplankton species in the study and their monthly presences

\begin{tabular}{|c|c|c|c|c|c|c|c|c|c|c|c|c|c|}
\hline Rotifera & Months & $\mathbf{J}$ & $\mathbf{F}$ & $\mathbf{M}$ & A & $\mathbf{M}$ & $\mathbf{J}$ & $\mathbf{J}$ & $\mathbf{A}$ & $\mathbf{S}$ & $\mathbf{O}$ & $\mathbf{N}$ & D \\
\hline \multirow{3}{*}{$\begin{array}{l}\text { Familya: } \\
\text { Philodinidae } \\
\text { Familya: } \\
\text { Collothecidae }\end{array}$} & Rotaria rotatoria (Pallas, 1766) & + & - & + & - & - & - & - & 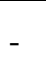 & + & - & - & + \\
\hline & Collotheca pelagica (Rousselet, 1893) & + & + & + & + & - & - & - & - & + & - & + & + \\
\hline & Collotheca mutabilis (Hudson, 1885) & - & - & - & + & + & - & - & - & - & - & + & + \\
\hline \multirow{3}{*}{$\begin{array}{l}\text { Familya: Filin } \\
\text { Familya: } \\
\text { Hexarthridae }\end{array}$} & Filinia terminalis (Plate, 1886) & - & 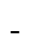 & + & - & - & - & - & 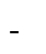 & - & - & - & + \\
\hline & Hexarthra intermedia (Wiszniewski, & - & - & + & 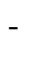 & - & - & - & - & - & + & + & - \\
\hline & Hexarthra oxyuris (Sernov 1903) & 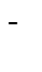 & - & - & - & + & - & - & - & - & - & - & - \\
\hline \multirow{6}{*}{$\begin{array}{l}\text { Familya: } \\
\text { Testudinellidae } \\
\text { Familya: } \\
\text { Asplanchnidae }\end{array}$} & Pompholyx sulcata (Hudson, 1885) & + & - & + & + & - & + & - & - & + & + & - & - \\
\hline & Asplanchna priodonta (Gosse, 1850) & + & + & + & + & + & + & + & + & + & + & + & + \\
\hline & Anuraeopsis fissa (Gosse, 1851) & . & 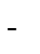 & . & ${ }^{\circ}$ & - & - & - & - & - & - & - & - \\
\hline & Brachionus quadridentatus (Hermann, & - & - & + & - & - & - & - & - & - & - & - & - \\
\hline & 1783) & . & 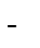 & + & + & - & - & - & . & - & - & + & - \\
\hline & Keratella cochlearis (Gosse, 1851) & - & - & + & - & - & - & - & - & - & - & - & - \\
\hline \multirow{3}{*}{$\begin{array}{l}\text { Familya: } \\
\text { Brachionidae }\end{array}$} & Keratella tecta (Lauterborn, 1900) & + & - & + & - & + & + & - & + & + & + & + & + \\
\hline & Keratella quadrata (Müller, 1786) & - & - & - & + & + & - & - & - & - & - & - & - \\
\hline & $\begin{array}{l}\text { Keratella tropica (Apstein, 1907) } \\
\text { Notholca squamula (Müller, 1786) }\end{array}$ & + & - & + & - & - & - & - & - & - & - & + & - \\
\hline \multirow{3}{*}{$\begin{array}{l}\text { Familya: Colurellidae } \\
\text { Familya: Euchlanidae } \\
\text { Familya: } \\
\text { Gastropodidae }\end{array}$} & Colurella adriatica (Ehrenberg, 1831) & - & - & - & + & - & - & - & 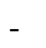 & - & - & - & - \\
\hline & Euchlanis dilatata (Ehrenberg, 18 & - & - & - & 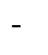 & - & - & - & 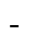 & + & - & - & + \\
\hline & Ascomorpha ovalis (Bergendahl, 1892) & - & - & - & - & + & + & - & + & + & + & + & - \\
\hline \multirow{2}{*}{ Familya: Lecanidae } & Lecane bulla (Gosse, 1886) & & 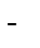 & 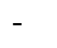 & & - & + & - & . & + & - & - & - \\
\hline & e lunaris (Ehre & 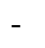 & - & + & . & + & - & + & + & + & + & + & - \\
\hline \multirow{2}{*}{$\begin{array}{l}\text { Familya: } \\
\text { Lepadellidae }\end{array}$} & Lepadella acuminata (Ehrenberg, & - & - & + & 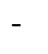 & - & - & - & - & - & - & - & - \\
\hline & $\begin{array}{l}\text { 1834) } \\
\text { Lepadella ovalis (Müller, 1896) }\end{array}$ & - & & + & - & - & + & - & - & - & - & - & - \\
\hline Familya: Mytilinidae & $\begin{array}{l}\text { Lophocharis salpina (Ehrenberg, } \\
1834 \text { ) }\end{array}$ & - & - & - & - & - & - & - & - & - & - & + & - \\
\hline \multirow{3}{*}{$\begin{array}{l}\text { Familya: } \\
\text { Notommatidae } \\
\text { Familya: } \\
\text { Synchaetidae }\end{array}$} & Cephalodella gibba (Ehrenberg, 1832) & - & - & + & - & - & - & - & - & - & + & - & - \\
\hline & Polyarthra dolichoptera (Idelson, & + & + & + & + & + & + & + & + & + & + & + & + \\
\hline & $\begin{array}{l}\text { Synchaeta pectinata (Ehrenberg, 1832) } \\
\text { Sing }\end{array}$ & - & + & + & + & - & + & - & - & - & - & + & + \\
\hline \multirow{2}{*}{$\begin{array}{l}\text { Familya: } \\
\text { Trichocercidae }\end{array}$} & Trichocerca similis (Wierzejski, 1893) & I & 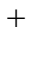 & + & 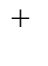 & + & . & + & + & + & - & + & + \\
\hline & $\begin{array}{l}\text { Trichocerca capucina (Wierzejski and } \\
\text { Zacharias, 1893) }\end{array}$ & - & + & - & - & - & + & + & - & - & - & - & - \\
\hline Trichotriidae & Trichotria tetractis (Ehrenberg, 1830) & - & + & - & - & - & - & - & - & - & - & - & - \\
\hline
\end{tabular}


Table 2. Continued

\begin{tabular}{|c|c|c|c|c|c|c|c|c|c|c|c|c|c|}
\hline $\begin{array}{l}\text { Rotifera } \\
\text { Cladocera }\end{array}$ & Months & $\mathbf{J}$ & $\mathbf{F}$ & $\mathbf{M}$ & $\mathbf{A}$ & $\mathbf{M}$ & $\mathbf{J}$ & $\mathbf{J}$ & $\mathbf{A}$ & $\mathbf{S}$ & $\mathbf{O}$ & $\mathbf{N}$ & $\mathbf{D}$ \\
\hline \multirow[t]{4}{*}{ Familya: Bosminidae } & Bosmina longirostris (Müller 1785) & + & + & + & + & + & + & + & + & + & + & + & + \\
\hline & Alona quadrangularis (Müller, 1776) & - & - & - & - & - & - & - & - & - & + & - & - \\
\hline & Alona rectangula (Sars, 1861) & - & - & - & - & - & - & - & - & - & + & - & + \\
\hline & Disparalona rostrata (Koch, 1841) & + & - & - & - & - & - & - & - & - & - & - & + \\
\hline \multirow[t]{5}{*}{ Familya: Chydoridae } & Chydorus sphaericus (Müller, 1785) & - & - & - & - & + & - & - & - & - & - & - & - \\
\hline & Monospilus dispar (Sars, 1861) & - & - & - & - & - & - & - & - & - & + & - & 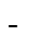 \\
\hline & Leydigia leydigi (Leydig, 1860) & - & - & - & - & - & - & - & + & - & - & - & - \\
\hline & Ceriodaphnia pulchella (Sars, 1862) & + & + & + & + & + & + & + & + & + & + & + & + \\
\hline & Daphnia galeata (Sars, 1864) & - & - & + & - & - & + & - & - & - & - & - & - \\
\hline \multirow[t]{2}{*}{ Familya: Daphniidae } & Daphnia longispina (Müller, 1785) & + & + & + & + & + & + & + & - & + & - & + & + \\
\hline & Daphnia cucullata Sars, 1862 & - & - & + & + & - & + & + & + & + & - & - & - \\
\hline Familya: Leptodoridae & Leptodora kindtii (Focke, 1844) & - & - & - & - & - & + & - & - & - & - & - & 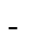 \\
\hline $\begin{array}{l}\text { Familya: } \\
\text { Macrothricidae }\end{array}$ & Macrothrix laticornis (Jurine, 1820) & - & - & - & - & - & - & - & - & - & + & - & + \\
\hline Familya: Moinidae & Moina micrura (Kurz, 1874) & - & - & + & - & - & + & - & - & + & + & - & + \\
\hline Familya: Sididae & $\begin{array}{l}\text { Diaphanosoma birgei (Korinek, } \\
\text { 1981) }\end{array}$ & + & - & + & - & - & + & + & + & + & + & + & - \\
\hline \multicolumn{14}{|l|}{ Copepoda } \\
\hline \multirow{6}{*}{ Familya: Cyclopidae } & Cyclops vicinus (Uljanin, 1875) & + & + & + & + & + & + & + & + & + & + & + & + \\
\hline & Diacyclops bicuspidatus (Claus, & + & + & + & + & + & + & + & - & + & - & + & + \\
\hline & 1857) & - & + & + & + & - & - & - & - & + & - & - & + \\
\hline & Macrocyclops albidus (Jurine, 1820) & - & - & - & - & + & - & - & - & - & - & - & - \\
\hline & Mesocyclops leukarti (Claus, 1857) & & & & & & & & & & & & \\
\hline & $\begin{array}{l}\text { Paracyclops } \quad \text { fimbriatus (Fischer, } \\
1853 \text { ) }\end{array}$ & - & - & - & - & - & - & - & - & - & + & & - \\
\hline Familya: Ameiridae & Nitocra hibernica (Brady, 1880) & - & - & - & - & - & - & - & - & - & - & - & + \\
\hline
\end{tabular}

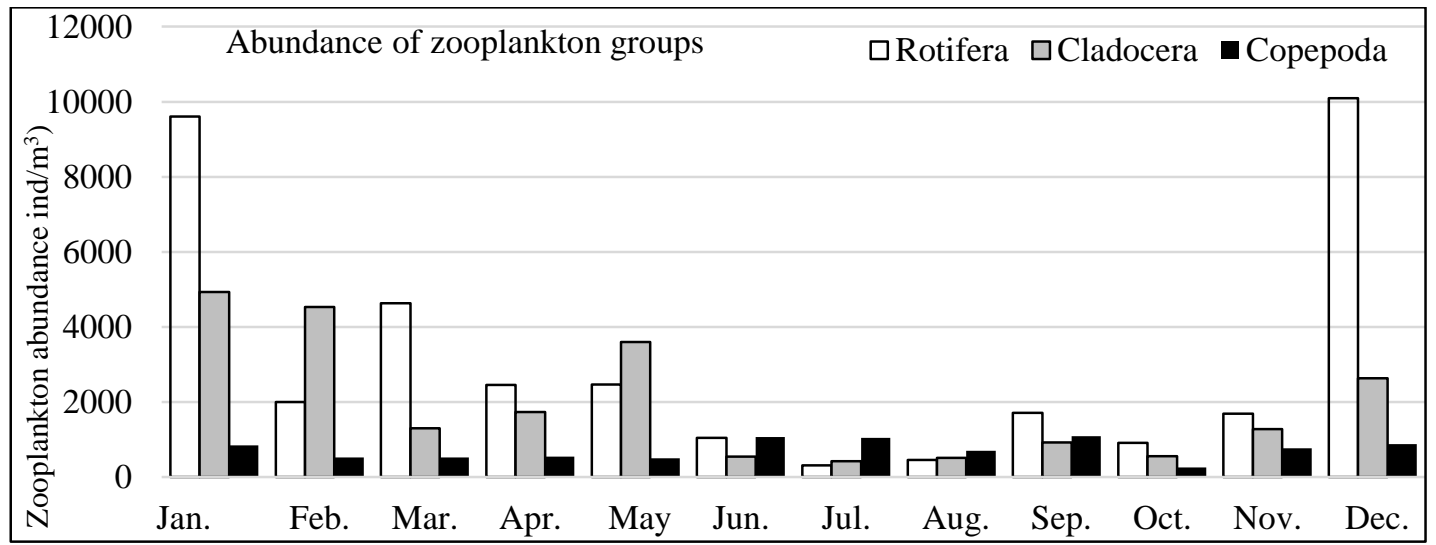

Figure 3. The abundance of zooplankton groups

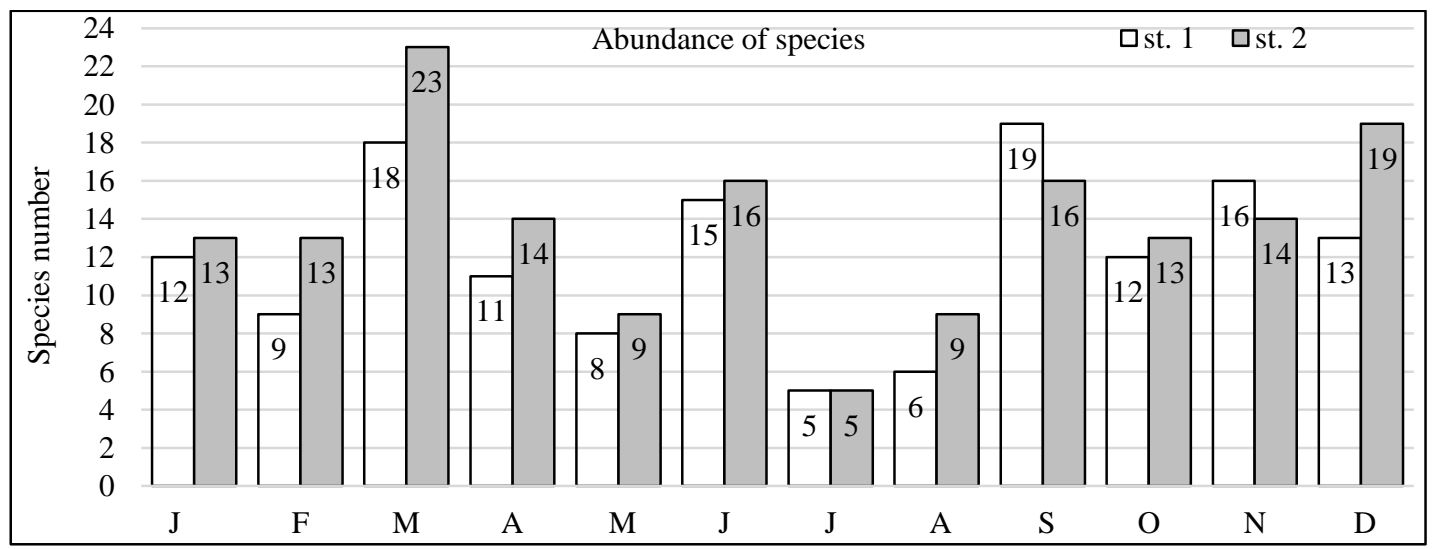

Figure 4. The species number of first and second stations 
The species found in the study every month in different abundance were Asplanchna priodonta, Polyarthra dolichoptera, Bosmina longirostris, Ceriodaphnia pulchella and Cyclops vicinus. Trichocerca similis 11 months, Daphnia longispina and Diacyclops bicuspidatus 10 months, Diaphanosoma birgei 8 months were found (Table 2). On the other hand, the species found only once were Hexarthra oxyuris, Anuraeopsis fissa, Brachionus quadridentatus, Colurella adriatica, Lepadella acuminata, Lophocharis salpina, Trichotria tetractis, Alona quadrangularis, Chydorus sphaericus, Monospilus dispar, Leydigia leydigi, Leptodora kindtii, Mesocyclops leukarti, Paracyclops fimbriatus and Nitocra hibernica (Table 2).

Total Rotifera was the most abundant in December $\left(10.099\right.$ ind. $\left./ \mathrm{m}^{3}\right)$, followed by January $\left(9.603\right.$ ind. $\left./ \mathrm{m}^{3}\right)$ and March $\left(4.636\right.$ ind. $\left./ \mathrm{m}^{3}\right)$. The amount of total Cladocera was the highest in January (4928 ind. $\left./ \mathrm{m}^{3}\right)$, followed by February $\left(4.530\right.$ ind. $\left.\mathrm{m}^{3}\right)$ and May $\left(3.547\right.$ ind. $\left./ \mathrm{m}^{3}\right)$. The abundance of copepod was lesser than the other two groups and the most in September $\left(1.091\right.$ ind.$\left./ \mathrm{m}^{3}\right)$, then in June $\left(1.070\right.$ ind. $\left./ \mathrm{m}^{3}\right)$ and July $\left(1.042\right.$ ind.$\left./ \mathrm{m}^{3}\right)$. Rotifera and Cladocera were found the least in July (316 ind. $/ \mathrm{m}^{3}, 421 \mathrm{ind} . / \mathrm{m}^{3}$ ), but Copepoda was found the least in October (258 ind./ $/ \mathrm{m}^{3}$ ) (Figure 3).

The most species were found at station 2 (23 species) in March, followed by 19 species in September (1st station) and December (2nd station). The least species were found in both first two stations in July (5 species) (Figure 4).

\section{Discussion}

The physicochemical parameters and zooplankton communities together form a comprehensive ecosystem and as in any ecosystem, there is interaction between the zooplankton and also between the phytoplankton and the water quality parameters. These interactions are directly or indirectly subjected to the complex influences, some of which results in quantitative changes (Welch 1952).

Determined water quality parameters, for animals in water are observed to be within the normal values. According to this, water temperature values $\left(7.97-24.57{ }^{\circ} \mathrm{C}\right)$ detected in the study generally reflect the climatic conditions of the region and they are ideal for zooplankton life and development.

Mean dissolved oxygen concentrations were above $5 \mathrm{mg} / \mathrm{l}(5.87-8.20 \mathrm{mg} / \mathrm{l})$ which was enough to support aquatic life, especially the zooplankton community (Karpowicz and Ejsmont-Karabin 2017).
The $\mathrm{pH}$ range in this study was $6.75-9.42$, which was consistent with the reports of Blouin (1989), Beklioglu and Moss (1995). According to these researchers the distribution of plankton species in lakes with $\mathrm{pH}$ levels of 3.5-7.6, Beklioglu and Moss (1995) noted that plankton never occurred at low and high $\mathrm{pH}$ values ( $\mathrm{pH}<4.6$ and $11<$ ).

Since chlorophyll $a$ values were found to be quite low (1.71-7.39 mg/m $\mathrm{m}^{3}$ ), dam lake was in oligomesotrophic character, according to Wetzel (1975).

All inorganic forms of nitrogen $\left(\mathrm{NO}_{3}{ }^{-}, \mathrm{NO}_{2}{ }^{-}\right.$and $\mathrm{NH}_{4}{ }^{+}$) can be used by aquatic plants and algae (Tepe and Boyd 2002). If these inorganic forms of nitrogen exceed $0.3 \mathrm{mg} / \mathrm{l}$ (as $\mathrm{N}$ ) in spring, it means there is enough nitrogen to support summer algal blooms. The concentrations of nitrogen forms in Kozan Dam Lake were enough to support algae blooms and indirectly zooplankton biomass.

The quality of reservoir waters generally varied between clean water and much polluted water throughout the year in terms of nitrite values (YSKY 2012). As the nitrate nitrogen values determined in the study were below $10 \mathrm{mg} / \mathrm{l}$, thus the reservoir waters were in the category of clean and less polluted water. The amount of ammonium nitrogen in the water samples was $0.056-0.187 \mathrm{mg} / \mathrm{l}$. According to the Regulation on Surface Water Quality (YSKY), these values showed that, dam lake waters are classified as second class polluted waters.

Orthophosphate values changed between $0.01 \mathrm{mg} / \mathrm{l}$ and $0.053 \mathrm{mg} / \mathrm{l}$ and the reservoir waters generally have the first-class clean water and the second-class polluted water in terms of phosphate according to the YSKY (2012).

As a result, according to the Regulation on Surface Water Quality, reservoir water was first class water in point of temperature, dissolved oxygen, $\mathrm{NH}_{4}-\mathrm{N}, \mathrm{PO}_{4}-\mathrm{P}$, second class water in point of conductivity, $\mathrm{pH}, \mathrm{NO}_{3}-\mathrm{N}$ and third class water in point of $\mathrm{NO}_{2}-\mathrm{N}$ (YSKY 2012).

In terms of aquatic organisms, the acceptable electrical conductivity value was reported to be $250-500 \mu \mathrm{S} / \mathrm{cm}$ by Yücel (1990). The lowest conductivity of the study was determined as $372.1 \mu \mathrm{S} / \mathrm{cm}$, the highest $436.1 \mu \mathrm{S} / \mathrm{cm}$, and accordingly, the dam lake was among the acceptable values for the aquatic organisms.

A total of 50 zooplankton species were detected, including 29 from rotifers, 15 from cladocerans and 6 from copepods. Twenty-two zooplankton species were previously reported in a study conducted in Kozan Dam Lake (Bozkurt 2004b). Some of the species Collotheca ornata (Ehrenberg 1832), Cyclops abyssorum Sars, 1863, Acanthodiaptomus denticornis (Werzesski 1887) and 
Craspedacusta sowerby (Lankester 1880) were not found in the present study. On the other hand, 33 of the 50 zooplankton species in the present study were not reported in the previous study. It is thought that the difference of species in the two studies may depend on the number of sampling and the time difference between studies.

Rotifera was the dominant group followed by Cladocera and Copepoda among zooplankton groups qualitatively and quantitatively in Kozan Dam Lake as in all freshwater ecosystems (Saksena 1987).

It is reported that most of the zooplankton species found in the study are widespread in water bodies of all sizes in different geographic regions, with different types of substrates and vegetation-related species (Hutchinson 1967; Ruttner-Kolisko 1974; Braioni and Gelmini 1983; Ryding and Rast 1989; Ramdani et al. 2001; Eldredge and Evenhuis 2003). They were widespread in Turkey and worldwide because they were found in almost all regions of Turkey (Güher 2000; Alper et al. 2007; Dirican and Musul 2008; Saler and İpek 2009; Y1ldız et al. 2010; Günsel and Emir Akbulut 2012; Apaydın Yağc1 2013; Güher 2014; Saler and Alıș 2014; Apaydın Yağc1 et al. 2015; Güher and Çolak 2015; Ustaoğlu 2015; Gürel and Saler 2015) and they were reported from lots of study inland waters of Turkey (Ustaoğlu et al. 2004; Ustaoğlu 2015).

The species identified in Kozan Dam Lake have been reported in various studies in the region and in the vicinity (Table 3). According to this, Bosmina longirostris was reported from 23 different studies in the region. While Cephalodella gibba was reported in 21 studies, Lecane lunaris was reported in 20 studies. Keratella cochlearis in 19 studies, Euchlanis dilatata and Lecane bulla in 18 studies, Colurella adriatica and K. quadrata in 17 studies, K. tecta and Alona rectangula in 16 studies were reported. Chydorus sphaericus and Diaphanosoma birgei were found in 15 studies, at the same time Lepadella ovalis, Polyarthra dolichoptera, Trichotria tetractis and Ceriodaphnia pulchella found in 13 studies. In the region, species found in 12 different working areas Notholca squamula and Cyclops vicinus, but species found in 11 different areas Ascomorpha ovalis, Asplanchna priodonta, Collotheca pelagica, Lophocharis salpina, Trichocerca similis and Moina micrura. Other species, Keratella tropica and Nitocra hibernica (10), Macrothrix laticornis (9), Brachionus quadridentatus, Daphnia longispina,
Mesocyclops leukarti and Paracyclops fimbriatus (8), Pompholyx sulcata, Daphnia galeata Disparalona rostrata, Diacyclops bicuspidatus and Macrocyclops albidus (7), Collotheca mutabilis (6), Anuraeopsis fissa (5), Filinia terminalis, Hexarthra oxyuris, Lepadella acuminata, Trichocerca capucina, Leydigia leydigi (4), Synchaeta pectinata (3), Hexarthra intermedia, Rotaria rotatoria, Alona quadrangularis, Daphnia cucullata, Leptodora kindtii, (2), Monospilus dispar (1) have been reported from less aquatic environment. It has also been reported that these species are found all or nearly all of the sampling periods (Bozkurt 1997; Bozkurt 2004a, 2004b; Bozkurt and Dural 2005; Bozkurt 2006; Bozkurt and Sagat 2008; Bozkurt et al. 2009; Bozkurt and Göksu 2010; Bozkurt and Güven 2010; Bozkurt and Tepe 2011; Ülgü and Bozkurt 2015; Bozkurt and Duysak 2016; Bozkurt 2016; Bozkurt and Aktaş 2016; Bozkurt 2017; Bozkurt and Genç 2018a, 2018b; Bozca and Bozkurt 2018; Bozkurt et al. 2018).

The presence of identified species in the study seems to be compatible with their ecological characters and distribution.

There were differences in the number and amount of zooplankton species in the first and second stations. According to field observations, this may be due to the water flow rate, water mix and depth differences. On the other hand, the significant and inverse relationship $\left(\mathrm{R}^{2}=-0.65\right)$ was found between the dissolved oxygen and the number of species in the 2nd station, while the low level of significance and the inverse relationship $\left(\mathrm{R}^{2}=-0.33\right)$ were determined in the first station. Zooplankton are not directly related to the nutrient, but have an indirect relationship because nutrient affects the presence of phytoplankton or other forms of zooplankton's food (Khan 2003). Thus, zooplankton growth, development, population density and species diversity were affected by the abundance of nutrient. Similarly, in the second station, significant relationship $\left(\mathrm{R}^{2}=0.88, \mathrm{R}^{2}=0.68\right)$ was determined between nitrite and species number, and chlorophyll $a$ and species number, while the significance level in the first station was low $\left(\mathrm{R}^{2}=0.29, \mathrm{R}^{2}=0.4031\right)$ relationship was determined. Our results revealed that the level of relationship between other parameters and species numbers was very low in the Kozan dam lake. 
Table 3. Distribution of species in our study in the region, according to the studies conducted by various researchers

\begin{tabular}{|c|c|c|}
\hline Species & & Study area \\
\hline A. fissa & 5 area & $5,7,9,10,13$ \\
\hline A. ovalis & $11 "$ & $3,4,5,6,9,10,14,15,16,21,24$ \\
\hline A. priodonta & $11 "$ & $2,4,5,6,9,10,12,14,15,20,24$ \\
\hline B. quadridentatus & $8 "$ & $5,10,11,12,13,16,18,20$ \\
\hline C. gibba & $21 "$ & $1,2,3,4,6,8,9,10,11,12,13,14,15,16,17,18,20,21,22,23,24$ \\
\hline C. mutabilis & $6 "$ & $10,13,14,15,20,24$ \\
\hline C. pelagica & $11 "$ & $3,6,9,10,11,14,16,17,19,20,21$ \\
\hline C. adriatica & $17 "$ & $1,2,3,4,6,8,9,12,13,14,15,16,17,20,21,22,23$ \\
\hline E. dilatata & $18 "$ & $1,2,3,4,8,10,11,12,13,14,16,17,18,20,21,22,23,24$ \\
\hline F. terminalis & $4 "$ & $9,10,14,18$ \\
\hline H. intermedia & $2 "$ & 14,18 \\
\hline H. oxyuris & $4 "$ & $13,14,17,21$ \\
\hline K. cochlearis & $19 "$ & $1,2,3,4,5,6,7,9,10,11,12,13,14,15,16,17,19,20,21$ \\
\hline K. quadrata & $17 "$ & $1,2,6,7,9,10,11,12,13,14,15,16,17,18,20,21,24$ \\
\hline K. tecta & $16 "$ & $3,4,7,9,10,11,12,14,15,17,19,20,21,22,23,24$ \\
\hline K. tropica & $10 "$ & $7,10,11,12,15,16,17,19,20,24$ \\
\hline L. bulla & $18 "$ & $1,3,6,7,8,10,12,13,14,16,17,18,19,20,21,22,23,24$ \\
\hline L. lunaris & $20 "$ & $1,2,3,4,5,6,8,9,10,12,13,14,15,17,19,20,21,22,23,24$ \\
\hline L. acuminata & $4 "$ & $2,3,4,17$ \\
\hline L. ovalis & $13 "$ & $1,2,4,5,8,10,12,13,14,20,21,22,23$ \\
\hline L. salpina & $11 "$ & $5,6,9,10,12,13,16,17,20,21,23$ \\
\hline N. squamula & $12 "$ & $1,9,10,11,12,13,14,15,16,17,18,20$ \\
\hline P. dolichoptera & $13 "$ & $10,11,12,13,14,15,16,17,18,19,20,21,24$ \\
\hline P. sulcata & $7 "$ & $7,9,11,12,14,19,20$ \\
\hline$R$. rotatoria & $2 "$ & 20,22 \\
\hline S. pectinata & $3 "$ & $8,14,20$ \\
\hline T. similis & $11 "$ & $1,2,3,5,6,9,10,14,15,21,24$ \\
\hline T. capucina & $4 "$ & $9,14,15,20$ \\
\hline T. tetractis & $13 "$ & $1,4,12,13,14,15,16,17,20,21,22,23,24$ \\
\hline A. quadrangularis & $2 "$ & 9,24 \\
\hline A. rectangula & $16 "$ & $3,5,6,7,9,11,12,13,14,15,16,17,18,20,21,24$ \\
\hline B. longirostris & $23 "$ & $1,2,3,4,5,6,7,9,10,11,12,13,14,15,16,17,18,19,20,21,22,23,24$ \\
\hline C. pulchella & $13 "$ & $2,3,5,7,9,10,11,12,13,15,19,20,24$ \\
\hline C. sphaericus & $15 "$ & $1,2,4,6,7,9,11,12,13,14,15,17,18,20,24$ \\
\hline D. longispina & $8 "$ & $5,6,9,10,14,15,20,24$ \\
\hline D. cucullata & $2 "$ & 15,24 \\
\hline D. galeata & $7 "$ & $1,3,4,14,15,20,24$ \\
\hline D. birgei & $15 "$ & $1,2,3,4,5,6,9,10,11,14,15,17,19,20,24$ \\
\hline D. rostrata & $7 "$ & $4,5,9,10,14,20,24$ \\
\hline L. kindtii & $2 "$ & 14,15 \\
\hline L. leydigi & $4 "$ & $9,10,11,14$ \\
\hline M. laticornis & $9 "$ & $1,6,9,10,11,12,14,15,16$ \\
\hline M. micrura & $11 "$ & $7,10,11,12,13,14,16,17,18,19,24$ \\
\hline M. dispar & $1 "$ & 5 \\
\hline C. vicinus & $12 "$ & $4,5,6,7,9,11,14,15,17,18,19,20$ \\
\hline D. bicuspidatus & $7 "$ & $8,9,11,12,13,15,18$ \\
\hline M. albidus & $7 "$ & $2,8,9,12,13,15,24$ \\
\hline M. leukarti & $8 "$ & $8,10,11,13,16,18,19,20$ \\
\hline N. hibernica & $10 "$ & $1,8,9,12,13,15,18,20,23,24$ \\
\hline P. fimbriatus & $8 "$ & $8,9,10,12,13,18,21,22$ \\
\hline
\end{tabular}

(1: Kasımbey Creek, Hatay, 2: Hoplar Creek, Hatay, 3: Yayladağı Dam Lake, Hatay, 4: Hisarcık Dam Lake, Hatay, 5: Guvecci Dam Lake, Hatay, 6: Gorentaş Dam Lake, Hatay, 7: Volcanic pond, Gaziantep, 8: Sarıseki Marshes, Hatay, 9: Kahramanmaraş, 10: Seyhan Dam, Adana, 11: Tahtaköprü Dam, Gaziantep, 12: Gölbaşı Lake, Hatay, 13: Gölkent Lake, Hatay, 14: Aslantaş Dam, Osmaniye, 15: Birecik Dam, Şanlıurfa, 16: Yenişehir Lake, Hatay, 17: Topboğazı Dam, Hatay, 18: Yarseli Dam, Hatay, 19: Yagızlar Dam, Adana, 20: Ceyhan River, Adana, 21: Keşiş River, Osmaniye, 22: Savrun Stream, Osmaniye, 23: Deliçay Stream, Adan, 24. Manavgat River, Antalya).

\section{References}

Alekseev VR. 2002. Copepoda. In: Fernando C.H., editor. A guide to tropical freshwater zooplankton: identification, ecology and impact on fisheries, Leiden, The Netherlands: Backhuys Publishers. p. 123-187.

Alper A, Çelebi E, Çam H, Karaytuğ S. 2007. Cladocera and copepoda (crustacea) fauna of İkizcetepeler Dam
Lake (Balıkesir, Turkey). Turk J Fish Aquat Sc, 7: 71-73.

Apaydın Yağcı M. 2013. Seasonal zooplankton community variation in Karataş Lake, Turkey. Iran J Fish Sci. 12 (2): 265-276.

Apaydın Yağcı M, Yılmaz S, Yazıcıŏlu O, Polat N. 2015. The zooplankton composition of Lake Ladik 
(Samsun, Turkey). Turk J Zoo. 39: 652-659. doi: 10.3906/zoo-1312-54

Ayodele HA, Adeniyi IF. 2006. The zooplankton fauna of six impoundments on River Osun, Southwest,

Nigeria, The Zoologist, 1(4): 49-67. doi: 10.4314/tzool.v4i1.45213

American Public Health Association (APHA). 1995. Standard Methods for the Examination for Water and Wastewater (19th edition). Byrd Prepess Springfield, Washington.

Beklioglu, M. and Moss, B. 1995. The impact of $\mathrm{pH}$ on interactions among phytoplankton algae, zooplankton and perch (Perca fluviatilis) in a shallow, fertile lake. Freshwater Biol. 33(3):497-509. doi: 10.1111/j.1365-2427.1995.tb00409.x

Benzie JAH. 2005. The Genus Daphnia (including Daphniopsis)(Anomopoda: Daphniidae), Leiden: Backhuys Publishers,: 377 p.

Blouin AC. 1989. Patterns of plankton species, ph and associated water chemistry in Nova Scotia Lakes. Water Air Soil Poll 46 (1-4): 343-358. doi: 10.1007/BF00192869

Bozkurt A. 1997. Seyhan baraj gölü (adana) zooplanktonu. [Master's Thesis]. Çukurova University Institute of Natural and Apllied Sciences 69 p. [in Turkish]

Bozkurt A. 2004a. Akdeniz Bölgesi'ndeki bazı akarsuların zooplankton (rotifer, cladocer ve copepod) faunas1 üzerine ilk gözlemler. Türk Sucul Yaşam Dergisi, 65-70. [in Turkish]

Bozkurt A. 2004b. Doğu Akdeniz Bölgesindeki bazı baraj ve göletlerin zooplankton faunası üzerine ilk gözlemler. Türk Sucul Yaşam Dergisi, 2(3):71-76. [in Turkish]

Bozkurt A. 2006. Yenişehir Gölü (Reyhanlı, Hatay) Zooplanktonu. E.U. Journal of Fisheries \& Aquatic Sciences. 23(1/1):39-43. [in Turkish]

Bozkurt A. 2016. Zooplankton of Kilavuzlu Dam Lake (Kahramanmaraş) and the effect of cage fish farming on water quality and zooplankton fauna of the Dam Lake. Journal of Aquaculture Engineering and Fisheries Research. 2(3):97-108. doi: 10.3153/JAEFR16012

Bozkurt A. 2017. First Record of Epactophanes richardi Mrázek, 1893 (Copepoda, Harpacticoida, Camptocamptidae) for Turkish Inland Waters. Turk J Fish Aquat Sci. 17:25-29. doi:10.4194/1303-2712-v17_1_04

Bozkurt A, Genç MA. 2018a. Zooplankton fauna of some temporary volcanic lakes in Gaziantep. Journal of Limnology and Freshwater Fisheries Research. 4(2):118-121. doi:10.17216/LimnoFish.354205

Bozkurt A, Genç MA. 2018b. Detection of zooplankton fauna in downstream of euphrates. Jorunal of Limnology and Freshwater Fisheries Research. 4(1):13-16.

doi: 10.17216/LimnoFish.352108

Bozca M, Bozkurt A. 2018. Zooplankton Fauna of Four Dam Lakes in Yayladağ (Hatay). Paper presented at: 3rd International Mediterranean Science and Engineering Congress: Adana, Turkey.
Bozkurt A, Bozça M, Kaya D. 2018. Zooplankton fauna of two streams in Hatay (Turkey). Paper presented at: 13th International Symposium on Fisheries and Aquatic Sciences. Ankara, Turkey.

Bozkurt A, Aktaş M. 2016. Distribution of cladocera species in different waters of Turkey. Journal of Limnology and Freshwater Fisheries Research. 2(3):137-143.

doi: 10.17216/LimnoFish.279722

Bozkurt A, Duysak T. 2016. Türkiye'de farklı içsu rezervuarlarındaki zooplankton dağılımı ve tür çeşitliliğinin araştırılması. Paper presented at: 1st International Mediterranean Science and Engineering Congress (IMSEC); Adana, Turkey.

Bozkurt A, Göksu MZL, Altun A. 2009. Cladocera and copepoda fauna of Aslantaş Dam Lake (OsmaniyeTurkey). Journal of FisheriesSciences.com. 3(4): 285-297. doi: 10.3153/jfscom.2009033

Bozkurt A, Tepe Y. 2011. Zooplankton composition and water quality of Lake Gölbaşı (Hatay-Turkey). Fresenius Environmental Bulletin, 20 (1a):166-174.

Bozkurt A, Göksu MZL. 2010. Composition and vertical distribution of rotifera in Aslantas Dam Lake (Osmaniye-Turkey). Journal of Fisheries Sciences.com. 4(1):38-49. doi: 10.3153/jfscom.2010005a

Bozkurt A, Güven SE. 2010. Asi Nehri (Hatay-Türkiye) zooplankton süksesyonu. Journal of FisheriesSciences.com. 4(4):337-353. [in Turkish] doi: 10.3153/jfscom.2010037.

Bozkurt A, Sagat Y. 2008. Birecik Baraj Gölü zooplaktonunun vertikal dağılımı. Journal of FisheriesSciences.com. 2(3):332-342. [in Turkish] doi: 10.3153/jfscom.mug.200721.

Bozkurt A, Dural M. 2005. Topboğazı Göleti (Hatay) zooplanktonunun vertikal göçü. Türk deniz araştırmaları, 105-110. [in Turkish]

Bozkurt A, Dural M, Yilmaz AB. 2004. Yarseli Baraj Gölünün (Hatay/Türkiye) bazı fiziko-kimyasal özellikleri ve zooplankton (Rotifer, Cladocer ve Copepod) faunası. Türk Sucul Yaşam Dergisi. 2(3):307-317. [in Turkish]

Braioni MG, Gelmini D. 1983. Guide per il reconoscimento delle specie animali delle acque interne Italiane: Rotiferi monogononti. Italy: Consiglio Nazionalie delle Ricerche, $181 \mathrm{p}$.

Brandl Z. 2002. Methodology and general ecology, In: Fernando C. H., editor. A Guide to tropical freshwater zooplankton: identification, ecology and impact on fisheries, Leiden, The Netherlands: Backhuys Publishers. p. 1-21.

De Smet WH. 1996. The Prolidae (Monogononta), Vol, 4, SPB Academic Publishing, Amsterdam.

De Smet WH. 1997. The Dicranophoridae (Monogononta), Vol, 5, SPB Academic.

Dirican S, Musul H. 2008. Çamlıgöze Baraj Gölü (Sivas-Türkiye) Zooplanktonu faunası üzerine bir çalışma. SDÜ Fen Bilimleri Dergisi, 12(1): 17-21. [in Turkish] 
Dodson SI 1974. Adaptive change in plankton morphology in response to size-selective predation: A new hypothesis of cyclomorphosis. Limnol Oceanogr. 19(5):721-729.

doi: 10.4319/lo.1974.19.5.0721

Dussart B. 1967. Les copepodes des eaux continentales d'urope occidentale, tome I: calanoides et harpacticoides. Paris: Editions N. Boublee\&Cie, 500 p. doi: 10.1002/iroh.19680530126

Edmondson WT. 1959. Methods and Equipment, in, Fresh-Water Biology. Second Education, New-York: John Wiley and Sons, $1202 \mathrm{p}$.

Eldredge LG, Evenhuis NL. 2003. Hawaii's Biodiversity: a Detailed Assessment of the Numbers of Species in The Hawaiian Islands. Bishop Museum Occasional Paper No 76, Bishop Museum Press, Honolulu, 28 pp.

Güher H. 2000. A faunistic study on the freshwater cladocera (Crustacea) species in Turkish Thrace (Edirne, Tekirdağ, Kirklareli). Turk J Zool. 24:237-243.

Güher H. 2014. A checklist for zooplankton (Rotifera, Copepoda, Cladocera) of European Turkey inland waters. Ege J Fish Aqua Sci. 31(4):221-225. doi:10.12714/egejfas.2014.31.4.08

Güher H, Çolak Ş. 2015. Süloğlu Baraj Gölü’nün (Edirne) zooplankton (Rotifera, Cladocera, Copepoda) faunası ve mevsimsel değişimi. Trakya University Journal of Natural Sciences. 16(1):17-24. [in Turkish]

Günsel S, Emir Akbulut N. 2012. The investigation of the zooplanktonic organisms of Delice River and its arms in Kizılırmak River basin (Turkey). Hacettepe Journal of Biological \& Chemical, Special Issue. 40(4):309-316.

Gürel Ö, Saler S. 2015. Zooplankton of Orduzu Pond (Malatya) Frrat University Journal of Science, 27(1): 21-28. [in Turkish].

Hołynska M, Reid JW, Ueda H. 2003. Copepoda: Cyclopoida genera Mesocyclops and Thermocyclops, In: Ueda H, Reid JW, editors. Guides to the identification of the microinvertebrates of the continental waters of the world. Leiden: Backhuys Publishers, p 213.

Hutchinson GE. 1967. A treatise of limnology. Vol. 2. New York.: John Wiley and Sons, 1115 p. doi: 10.4319/lo.1969.14.3.0472

Karpowicz M, Ejsmont-Karabin J. 2017. Effect of metalimnetic gradient on phytoplankton and zooplankton (Rotifera, Crustacea) communities in different trophic conditions. Environ Monit Assess. 189(8): 354-367. doi: 10.1007/s10661-017-6055-7

Khan RA. 2003. Faunal diversity of zooplankton in freshwater wetlands of southeastern West Bengal. Records of the Zoological Survey of India, Occasional Paper, $107 \mathrm{p}$.

Kiefer F, Fryer G. 1978. Das zooplankton der binnengewässer, 2 Teil. Stuttgart: Schweizerbart'sche Verlagsbuchhandlung $380 \mathrm{p}$.

Koste W. 1978. Die Radertiere Mitteleuropas Ein Bestimmungswerk, Begründet Von Max Voigt, Überordnung Monogononta, 2 Auflage Neubearbeitet Von II, Tefelband. Berlin Stutgart: 234 p.
Lougheed VL, Chow-Fraser P. 2002. Development and use of a zooplankton index to monitor wetland quality in the Laurentian Great Lakes basin. Ecological Applications. 12(2):474-486.

doi:10.1890/10510761(2002)012[0474:DAUOAZ]2.0 $\mathrm{CO} ; 2$

Negrea ST. 1983. Fauna Republicii Socialiste Romania Vol, 4, 12, Crustacea Cladocera, Academia Republicii Socialiste Romania, Bucaresti, 339 p.

Nogrady T, Segers H. 2002. Rotifera vol, 6: Asplanchnidae, Gastropodidae, Lindiidae, Microcodidae, Synchaetidae, Trochosphaeridae and Filinia, Guide to the Identification of the Microinvertebrates of to the Continental Waters of the World, Leidenc (The Netherlands): Backhuys Publishers 264 p.

Ramdani M, Elkhiati N, Flower RJ, Birks HH, Kraïem MM, Fathi AA, Patrick ST. 2001. Open water zooplankton communities in North African wetland lakes: the CASSARINA Project. Aquatic Ecology, 35(3):319-333. doi: 10.1023/A:1011926310469

Ruttner- Kolisko A. 1974. Plankton rotifers. Biology and taxonomy. English translation of Die Binnengewasser v. 26, part $1.146 \mathrm{p}$. doi: 10.4319/lo.1976.21.1.0183b

Ryding SO, Rast W. 1989. The control of eutrophication of lakes and reservoirs. Man and the biosphere series Volume I. Lancaster: The Parthenon Publishing Group 314 p doi: 10.1002/iroh.19920770113

Saksena ND. 1987. Rotifers as indicators of water quality. Acta Hydroch et Hydrob. 15:482 - 485.

doi: 10.1002/aheh.19870150507

Saler S, Alış N. 2014. Zooplankton of Hancağız Dam Lake (Gaziantep-Turkey). Journal of Survey in Fisheries Sciences. 1(1):36-45.

doi: 10.18331/SFS2014.1.1.4

Saler S, İpek N. 2009. Cladocera and copepoda (crustacea) fauna of Seli Stream (Elazığ-Turkey). Journal of FisheriesSciences.com, 3(4):318-322.

doi: 10.3153/jfscom.2009036

Schulze PC, Folt CL. 1990. Food resources, survivorship, and reproduction of the omnivorous calanoid copepod Epischura lacustris. Ecology. 71(6):2224-2240. doi: 10.2307/1938635

Scourfield DJ, Harding JP. 1966, A key to the british species of freshwater cladocera, Scientific Publication No:5. New York: Freshwater Biological Association

Segers H. 1995. Rotifera, Volume 2: The Lecanidae (Monogononta). Guides to the identification of the microinvertebrates of the continental waters of the world, Volume 6 . The Hague, The Netherlands: SPB Academic Publishing 226 p.

Sharma BK. 1983. The Indian species of the genus Brachionus (Eurotatoria: Monogononta: Brachionida). Hydrobiology. 104:31-39. doi: 10.1007/BF00045949 
Tepe Y, Boyd CE. 2002. Nitrogen fertilization of Goldenshiner ponds. North American Journal of Aquaculture. 64: 284-289.

doi:10.1577/1548-8454(2002)064<0284:NFOGSP > 2 . $0 . \mathrm{CO} ; 2$

Ustaoğlu MR. 2015. An Updated Zooplankton Biodiversity of Turkish Inland Waters. Journal of Limnology and Freshwater Fisheries Research. 1(3):151-159. doi: 10.17216/LimnoFish-5000151941

Ustaoğlu MR, Balık S, Özdemir Mis D. 2004. The Rotifer Fauna of Lake Sazlıgol (Menemen, İzmir). Turkish Journal of Zoology. 28:267-272.

Ülgü M, Bozkurt A. 2015. Zooplankton Fauna of Tahtaköprü Dam Lake (Gaziantep). International Journal of Scientific and Technological Research. 1(1):203-215.

Welch PS. 1952. Limnology II edition. New York: Mc. Graw Hill Book Co.

Wetzel GR. 1975. Limnology. Philadelphia, London, and Toronto: W.B. Sauders 743 p.
Williamson CE, Butler NM. 1986. Predation on rotifers by the suspension-feeding calanoid copepod Diaptomus pallidus. Limnology \& Oceanography. 31(2): 393-402. doi: 10.4319/lo.1986.31.2.0393

Williamson CE. 1983. Invertebrate predation on planktonic rotifers. Hydrobiologia. 104(1): 385-396. doi: 10.1007/BF00045996.

Yildız U, Kemik ÖF, Hazer B. 2010. The removal of heavy metal ions from aqueous solutions by novel $\mathrm{pH}$ sensitive hydrogels. Journal of Hazard Mater 183 (1-3): 521-532. doi: 10.1016/j.jhazmat.2010.07.055

YSKY 2012. Yerüstü su kalitesi yönetmeliği (YSKY), 30.11.2012, RG No: 28483, Orman ve Su İşleri Bakanlığı, 28 s. [in Turkish].

Yücel A. 1990. Kırşehir-Seyfe Gölü bentik alg florası. Yüksek Lisans Tezi. Ankara Üniversitesi Fen Bilimleri Enstitüsü Biyoloji Anabilim Dalı. 137 s. [in Turkish].

Zaret TM. 1972. Predators, invisible prey and the nature of polymorphism in the cladocera (Class Crustacea). Limnology Oceanography. 17(2):171-184. doi: 10.4319/lo.1972.17.2.0171 